\title{
Seventh Berkshire Conference on the History of Women
}

\author{
Carole Turbin \\ Empire State College, SUNY \\ Sonya $O$. Rose \\ Colby College
}

The Berkshire Conference is unusual among academic meetings because it represents not only scholarship on women's history but also goals central to various aspects of the feminist movement. It is held every third year in June at a women's college in the Northeast. The 1987 conference, held at Wellesley College on June 19-21, was attended by more than two thousand scholars and provided an opportunity to consider not only the significance of recent research, but also the different paths taken by feminist scholars in the past two decades. The theme of the conference, "Beyond the Public/Private Dichotomy: Reassessing Woman's Place in History," produced panel topics covering the widening realms of scholarship on women's lives. The panels highlighted in this review, chosen with the interests of ILWCH's readers in mind, represent only a fraction of the topics in a three-day conference consisting of almost two hundred sessions on the history of more than half of humanity.

Alice Kessler-Harris's keynote address on pay equity or comparable worth introduced themes that were developed in a number of panels, especially those on the working class. Entitled "The Just Price, the Free Market, and the Value of Women," the talk was both a reminder to scholars of their responsibility to address public issues and an analysis of ways in which overly abstract models of gender differences have been misused both in scholarly analyses of women and in the political arena. Kessler-Harris pointed out that subjective judgements about social hierarchy are embedded in notions of equity and the just price. She argued that comparable worth has important implications because it challenges abstract definitions based on traditional ideas about gender differences. Redefinitions of equity reveal complexities about gender differences that provide a potential basis for challenging tradition.

Several panels explored the importance of the conversation between political engagement and scholarship, which is central to challenging inequality. Reflecting on the history of a movement that contributed to shaping the conference, a panel on socialist feminism and women's unions featured papers on the Chicago women's liberation movement and the Berkeley Women's Union. The panelists (Karen V. Hansen, Margaret Strobel, Ruth Rosen, and Mari Jo

International Labor and Working-Class History

No. 33, Spring 1988, pp. 99-101

(C) 1988 by the Board of Trustees of the University of Illinois 
Buhle) highlighted the extent to which political struggles of the 1960s and early 1970s have become a terrain for historical discourse. A panel on the politics of women's history took up a more specific question introduced by KesslerHarris's address: What happens to analyses of gender differences when they are used in advocacy cases? The panelists (Mary Frances Berry, Eileen Boris, Phillis Palmer, Deborah Bell, and Isabelle Katz Pinzler) argued that when differences are the subject of court decisions and union policies, the ambiguities, qualifications, and complexities inherent in good research are eliminated in order to clarify positions.

Panels on working-class women emphasized that recent efforts to explore the diversity of women's experience reveal the complexities of gender differences. A panel on nineteenth-century New England working women, which featured papers by Thomas Dublin, Mary Blewett, and Ava Baron (comments by Carole Turbin and Ileen DeVault), contributed to a more complex view of the family-wage economy, an analysis of the relationship between gender and skill that goes beyond technological definitions, and an exploration of the gender meanings underlying women wage-earners' political consciousness. A panel on disorderly women (Nancy Hewitt, Jacqueline Hall, Ardis Cameron, and Martha Ackelsberg) explored the extent to which labor militancy reflects not only unique circumstances, women's culture, and discrimination, but also reflects the complexities of the relationship between women's wage work and family life. Avoiding the view that women are either militant or not, the panelists stressed varieties of activism for women in different circumstances. They pointed to ways in which women labor activists saw close connections between activism, work life, and family concerns, for example, through their efforts to keep families together during strikes. A panel on British working-class women, which included papers by Ellen Ross and Judith Walkowitz (comments by Elaine Showalter), explored the social construction of motherhood and sexuality. An important theme was the relationship between the representation of mothers in terms of oppositional categories of good mothers or bad mothers and subjective notions of female sexuality.

Consideration of the meaning of gender differences was also reflected in panels dealing with women in a variety of cultural contexts ranging from ancient Roman civilization and colonial India to nineteenth- and twentiethcentury African, Latin American, and Islamic societies. Papers by Laura Lee Downs and Andrea Woollacott (with comments by Ruth Milkman and Judith Wishnia) on women's work in the French metals industry in the inter-war years and on munitions workers in World War I England explored the interplay among public policy, definitions of gender, and on-the-job experiences. The panelists' work revealed how different political ideologies can alter the influence of gender on the organization of work. The roundtable discussion of Gerda Lerner's The Creation of Patriarchy, which featured Jacqueline Jones, Margery Wolf, Ann Lane, and Mary Lefkowitz (comment by Gerda Lerner), 
also contributed to our understanding of gender differences. Panel members emphasized the ways in which patriarchy is socially constructed and developed through conflicts and struggles. They stressed the varieties of patriarchy in different periods and cultural contexts and the importance of understanding the interrelationship of gender, class, and race.

Kessler-Harris's argument that comparable worth reveals the social construction of gender differences suggests important directions for future scholarship. Feminists' efforts to redefine terms such as equity, justice, liberty, and power, coupled with scholarship on women's history, lead away from an exclusive focus on women. Instead, they move us toward an analysis of the cultural construction and the political appropriation of the ideas that shape the processes by which reality is socially constructed. 